\title{
Participatory injustice in Mexico's Readiness process to Reduce Emissions from Deforestation and forest Degradation (REDD +)
}

\author{
Horacio Almanza-Alcalde ${ }^{1} \cdot$ Poshendra Satyal ${ }^{2,3}$ [ $\cdot$ Esteve Corbera ${ }^{4}$ • Alma Patricia SotoSánchez ${ }^{1}$. \\ Martha Pskowski ${ }^{1}$
}

Accepted: 6 October 2021 / Published online: 18 October 2021

(C) The Author(s) 2021, corrected publication 2022

\begin{abstract}
Since 2007 many developing countries have laid groundwork for Reducing Emissions from Deforestation and forest Degradation and sustainable management and conservation of forests (REDD +) under the auspices of the United Nations Framework Convention on Climate Change (UNFCCC). REDD + is aimed at incentivizing forest conservation and management in developing countries through policy programmers and local projects, which should in theory enhance the participation of very diverse actors in forest policy and governance. Here we explore the early years of REDD + in Mexico focusing on the alleged "participatory" nature of the REDD + initiative. Based on interviews and field observations with those involved in drafting the REDD + national strategy and in the implementation of small-scale pilot project activities, we investigate the meaning of participation for REDD + actors, their aspirations in this regard, and how procedural justice issues are being considered in early policy implementation. We demonstrate that the process set in motion to draft the strategy did not sufficiently involve sub-national governance levels, thus reducing the legitimacy of REDD + efforts, particularly in rural communities. We suggest that rural local actors should be further involved in REDD + decision-making forums, be provided with more information for a good understanding of REDD + implementation (e.g., pilot projects), and most importantly, be given a real chance to implement REDD + activities grounded on their own institutions and land-use practices.
\end{abstract}

Keywords REDD $+\cdot$ Participation $\cdot$ Justice $\cdot$ Institutions $\cdot$ Land-use governance $\cdot$ Mexico

Poshendra Satyal

poshendra.satyal@birdlife.org

Horacio Almanza-Alcalde

halmanza.chih@inah.gob.mx

Esteve Corbera

Esteve.Corbera@uab.cat

Alma Patricia SotoSánchez

altzilal@gmail.com

Martha Pskowski

marthanelle@gmail.com

1 Instituto Nacional de Antropología E Historia (INAH), Ciudad Juarez, Mexico

2 BirdLife International, Cambridge, UK

3 School of International Development, University of East Anglia, Norwich, UK

4 Institute of Environmental Science and Technology \& Department of Geography, Universitat Autònoma de Barcelona, Bellaterra, Spain Institució Catalana de Recerca i Estudis Avançats (ICREA), Barcelona, Spain

\section{Introduction}

At the 11th Conference of the Parties (COP-11) of the United Nations Framework Convention on Climate Change (UNFCCC) in 2005, Costa Rica and Papua New Guinea led a coalition of countries that proposed an incentive-based mechanism to reduce emissions from deforestation and forest degradation (REDD). Subsequent negotiations expanded this proposal to encompass activities such as sustainable management of forests and conservation of existing forest carbon stocks, thus leading to the so-called REDD + framework. The framework is underpinned by seven UNFCCC policy decisions, brought together in 2013 under the Warsaw Framework for REDD +.

As of early 2021, REDD + has materialized through a number of multilateral, bilateral, and other donor-driven initiatives that have funded either developing country governments or civil society actors to lay the groundwork for REDD + development and implementation at national level. The World Bank Forest Carbon Partnership Facility (FCPF) 
and the UN-REDD program are the most well-known multilateral initiatives, through which over 650 million USD for the former and more than 280 million USD for the latter have been invested or pledged (FCPF, 2014; CONAFOR n.d.). Norway's development agency (NORAD) has been the world's most committed government agency to support REDD + policy design in host countries and the implementation of pilot projects.

Mexico is one of the countries that has received substantial bilateral and multilateral REDD + funding. The early years of REDD + in Mexico, i.e., the so-called "readiness phase" in policy jargon, consisted of developing institutional capacities, harmonizing regulations and policies, and building links and agreements between actors. These processes concluded with the approval of the national REDD + strategy in 2017 (Estrategia Nacional REDD +, hereafter ENAREDD +) (CONAFOR, 2016). The first draft was written in 2011, subsequently improved after several discussions in different forums, and finally put out for national consultation between 2014 and 2016 (Carrillo and Velasco 2016). In parallel, several small-scale, regional REDD + project activities were developed, mostly funded by the United States Agency for International Development (USAID) through a small grants programme managed by the Mexican NGO "Alianza Mexico REDD +" (AMREDD).

As REDD + host countries work towards devising ways to develop a common framework to understand land-use change processes and address the drivers of land-use emissions, through specific policy and institutional arrangements, they have also been encouraged to promote participatory processes under the well-established principle of extensive consultation with possible affected actors and Indigenous Peoples (International Labour Organization, 1989; UNDRIP, 2007), and do so in ways that respect and embrace institutional and social diversity (Daviet, 2011; Pham et al., 2014; Satyal, 2018). Decision 1/CP.16 of the UNFCCC (2011) makes explicit that:

“... the development of national strategies or action plans, policies and measures, and capacity-building, followed by the implementation of national policies and measures and national strategies or action plans that could involve further capacity-building, technology development and transfer and results-based demonstration activities, and evolving into results-based actions that should be fully measured, reported and verified', should entail 'broad country participation' (UNFCCC, 2011: Art. 73 and preamble) and they should ensure 'the full and effective participation of relevant stakeholders, inter alia indigenous peoples and local communities" (ibid: Art. 72).

Participation in public policy has been praised as an opportunity for transformation (Cernea, 1985; Chambers,
2000), as well as a potential effective instrument to pursue just policy designs and implementation, particularly if participation is carried out as a "longer term political project" (Hickey \& Mohan, 2005). For these reasons, the idea of participation has permeated the practice of advocacy groups and communities in rural and urban neighborhoods throughout Latin America, and it has influenced academic thinking in the social sciences particularly through the popular pedagogies of theorists and practitioners like Orlando Fals Borda and Paulo Freire. However, participation has also been criticized for being used as a smokescreen that contributes to serve the interests of a few actors, in ways that can be considered "tyrannical" (Cooke \& Kothari, 2001). Policy design and implementation have traditionally fallen short of adopting participatory approaches (Epstein \& Wickham-Crowley, 2011) and, despite the endorsement by most Latin American governments of treaties such as the United Nations International Covenant on Civil and Political Rights, participation mechanisms in public policy are often only adopted in response to continuous and strong collective action by civil society groups (Blauert et al., 2006). Any resulting spaces of dialogue have frequently served to open respectful atmospheres of discussion between the state and civil society organizations and people.

Here we investigate the alleged participatory character of Mexico's REDD+ "readiness process" by examining the decision-making forums that contributed to the final draft of the ENAREDD +, as well as the national consultation process leading to the approval of the strategy. Specifically, we ask: (a) how have actors (particularly local communities and civil society actors) participated in Mexico's REDD + "readiness process," (b) to what extent the actors' concerns about and priorities over REDD + have been recognized in these forums and the consultation process, and (c) what role has REDD + information-sharing played in enhancing or undermining actors' perspectives on the fairness of the decision-making processes (e.g., procedural justice)? By addressing these questions we elucidate the robustness of institutional calls for participation in REDD + and identify possible avenues for improving the participatory nature of REDD + activities in the present and future.

Several studies have already analysed participation dynamics in the context of REDD + readiness. Some authors have sought to understand the way non-state actors contribute to forest policymaking and influence the performance of REDD + design (Fujisaki et al., 2016; Lawlor et al., 2013; Satyal, 2018; Satyal et al., 2019). For example, Satyal et al. (2019) assessed the level of participation of different nonstate actors in Nepal's readiness phase and have shown that available forums of participation and decision-making in REDD + have been dominated by government actors and influential civil society groups, whereas the representation and influence of the country's marginalized groups have 
remained limited. Similarly, Lawlor et al. (2013) used a participation and benefits framework to assess the socioeconomic impacts of REDD + and concluded that local communities benefit from more secure tenure and empowerment. Benefits such as jobs and income derived from REDD + activities have been, however, rather insignificant. These questions have also been investigated in one-party countries such as Laos, where participation tends to be more restricted, and researchers argue that REDD + might be leading to improvements in participation (Boutthavong et al., 2017; Mustalahti et al., 2017).

We draw on procedural justice (also often referred to as participatory justice) to contribute to this growing of evidence from a novel angle, thus being concerned with the level of fairness governing decision-making and early activities about REDD + . Based on existing literature (Schlosberg, 2004; Sikor, 2014), we suggest that fairness in procedure can be achieved only if all actors who may be affected by REDD + participate, and in doing so they feel are being treated with dignity, given all information necessary to participate on an equal standing, listened to, and notice that both discussions held and any decisions adopted are impartial and transparent. Additionally, we suggest that procedural justice may only be realized if communities, social groups, and actors who have been historically marginalized in land-use planning and development projects participate "fully and effectively" in decision-making forums and consultations on the terms described above, and their concerns, values and institutions are taken into account in policy decisions and implementation vis-à-vis those of more powerful and often well represented actors. Procedural justice thus involves the presence of both the rights bearers and duty bearers (normally the state) (Broberg \& Sano, 2018; Sikor \& Stahl, 2011).

Communities' institutions, values, and their principle of self-determination (Sikor, 2014; Sikor \& Stahl, 2011) have been considered key aspects to account for in fair procedure (Young, 2000). In Mexico, these ideas are particularly associated with a sense of communal ethics, strongly rooted in community norms (Fuente \& Barkin, 2012; RendónMonzón \& Ballesteros-Rojo, 2003). The forms of customary law that underlie the successful model of sustainable community forestry and peasant agriculture among Indigenous Peoples in Mexico result from modern adaptations of precolonial political organization anchored to a commonly recognized territorial jurisdiction (Bayne et al., 2015; Chapela, 1999; Ellis et al., 2015). Therefore, it is our claim that full and effective participation should also encompass respect for environmental history, culture, and practices of any affected rural subjects, including but not only Indigenous Peoples.

In the following section we review the early years of REDD + readiness in Mexico and outline our methods. We then present our findings structured around the research questions and demonstrate that despite a committed deployment of resources and efforts in REDD+decision-making and consultation processes, existing forums and processes aimed at making REDD + participatory have failed to involve relevant local actors and address social and institutional mistrust. We follow this with a discussion of our findings and an opportunity to learn and build on communities' institutions, experiences, and values. Instead, efforts for wider participation have failed in meeting peoples' aspirations of procedural justice in REDD + and land-use governance more generally.

\section{Case Study and Methods}

Mexico is in a relatively advanced stage of REDD + readiness, with the principal activity from 2011 to 2017 being the development of the ENAREDD + (CONAFOR 2017). The country's readiness process involved the development of legal provisions that recognize the existence and value of ecosystem services for land-use policy, stressed the importance of mestizo and indigenous communities-who own approximately $55 \%$ of the country's land-in realizing REDD +, and incorporated the principle of sustainable rural development as a pillar of the ENAREDD + (McCall, 2016). Furthermore, the readiness process relied on a multiplicity of participatory activities, decision-making forums, policy instruments, and small-scale early action REDD + activities (Fig. 1).

Between 2013 and 2017, existing and emerging consultative decision-making forums and initiatives allowed bringing together some actors to discuss forest and rural development policies to inform the development of the ENAREDD + (Špirić et al. 2015). Subsequently, before its release in 2017, the ENAREDD + went through a consultation process of almost two years (CONAFOR, 2017). The consultation report details the national and international legal instruments that highlight the importance of consulting and involving indigenous peoples and local communities in decision-making (CONAFOR, 2016). However, the final text of the ENAREDD +, rather surprisingly, makes no mention of the obligation to Free, Prior, and Informed Consent principles (FPIC) (op. cit.) as established by international instruments (ILO, 1989).

We examine procedural fairness in the context of the Technical Consultative Committee (CTC) for REDD + and the national consultation process. The CTC was established in 2010 to serve as a nation-wide discussion platform to draft the country's REDD + strategy. Subnational CTCs were also established by every Mexican state to mimic the federal level initiative. These state-based CTCs also aimed to provide advice to the development of the ENAREDD +, gathering inputs from civil society members at state level 

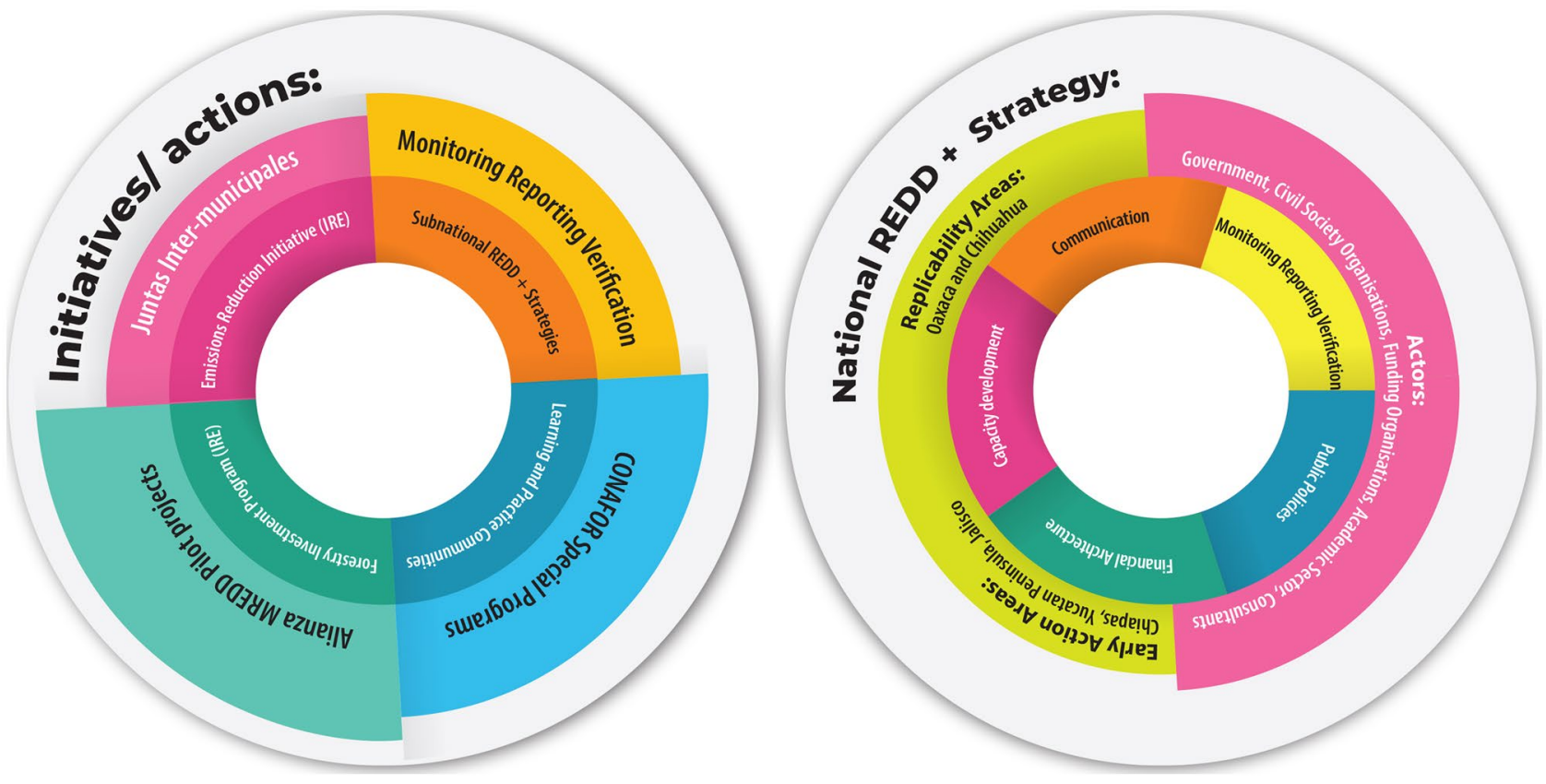

Fig. 1 National REDD + strategy and initiatives in Mexico

(Carrillo and Velasco 2016). The national strategy was mostly developed with inputs from the national CTC, integrating concerns from state-based committees. The national CTC held 31 events between 2008 and 2013 (CONAFOR, 2016), and other meetings that have not been officially recorded. ${ }^{1}$ All discussions held and decisions adopted informed the government's drafting of the national strategy (Fig. 2).

We conducted 180 semi-structured interviews and several participant observation activities between 2014 and 2016. We targeted a variety of actors who participated in national level CTC meetings and others who participated in sub-national meetings and who, most commonly, were involved in the implementation of REDD + pilot projects. Interviewees were selected through snowball sampling and included government staff (28), national and international NGO members (48), academics (20), community members participating in pilot projects (focus groups: 12; communitybased organisations: 17; individual community members: 6) and participants in REDD + related meetings and forums (see below) (14). Community participants belonged to seven communities in Oaxaca and 12 communities in the three states of the Peninsula, who participated in the small grants program of the AMREDD initiative (Fig. 3).

Semi-structured interviews were designed to explore interviewees' views and experiences of REDD + meetings

\footnotetext{
${ }^{1}$ Minutes of the meetings were posted online through CONAFOR's website and some meetings were broadcast live on YouTube: https:// www.youtube.com/user/AlianzaMREDD/videos
}

and their expectations and perceptions about a "just" REDD + policy process. We also asked questions about familiarity with and previous knowledge about REDD + and the extent to which information was available and accessible. Interviews were conducted using a checklist of participation-focused questions, but with some flexibility during the interviews to cover additional topics of interest. They were conducted in Spanish, in which all interviewees were sufficiently fluent. During the research period (2014-2016), project level interviews were carried out in a typical one-week visit, over approximately

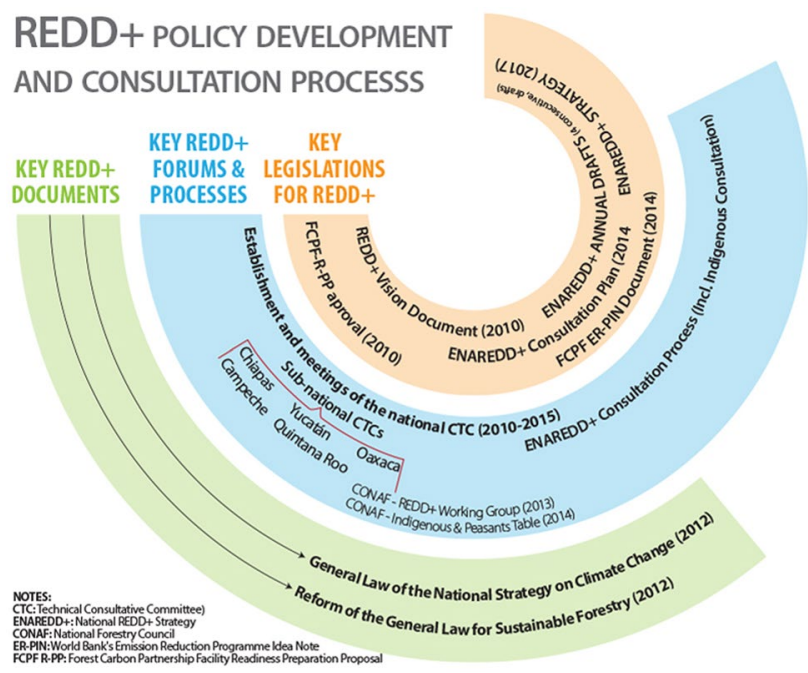

Fig. 2 REDD + policy development and consultation process 


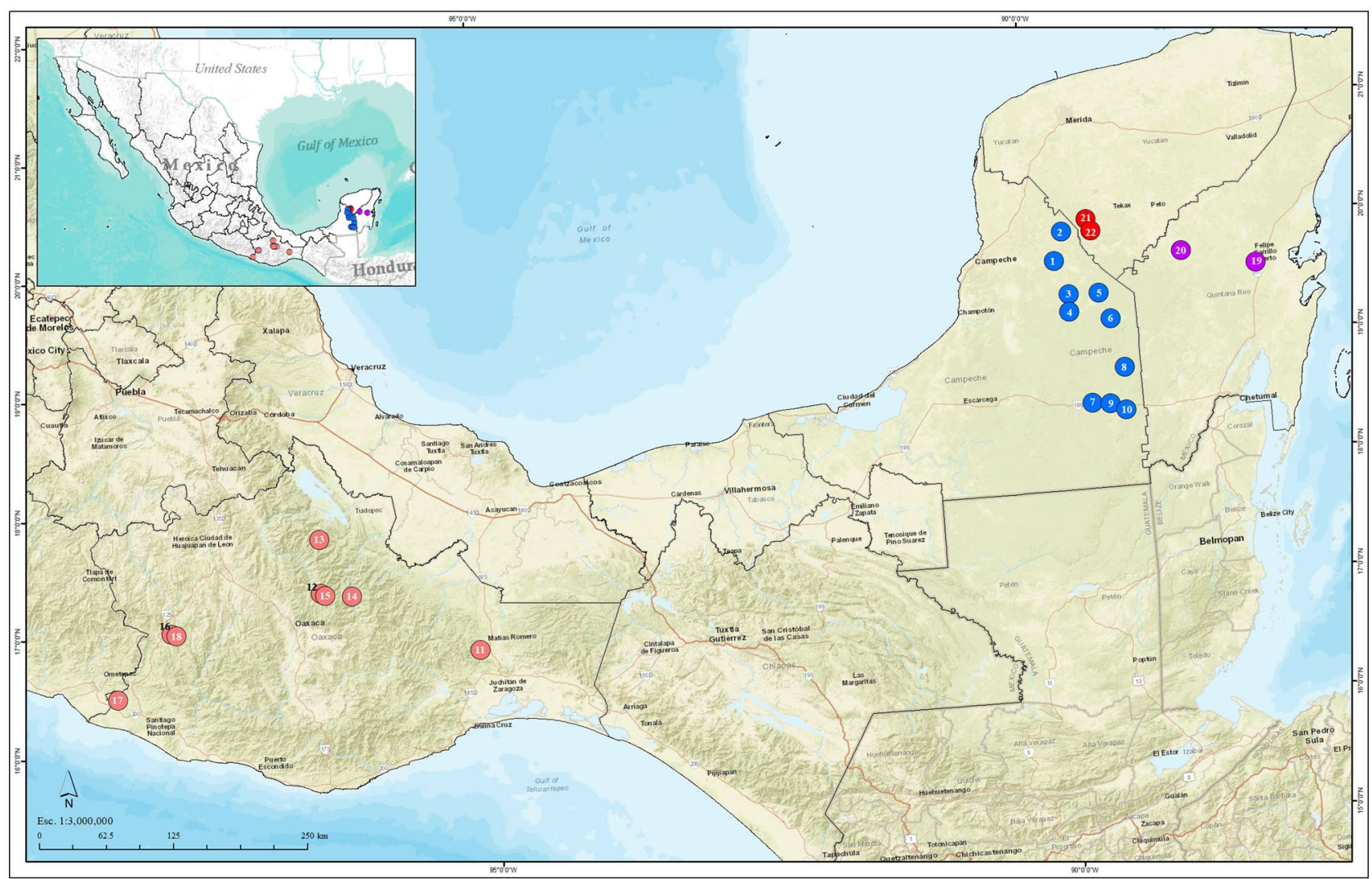

Fig. 3 REDD + implementation case study sites in Oaxaca, Yucatan, and Campeche

eight weeks annually. One research team member was based year-round in Merida, Mexico City, and Oaxaca de Juarez, making sporadic fieldwork visits to the communities, government offices, and workshops. All interviewees were informed about our research goal beforehand, consent for interviewing was sought, and recording used when accepted and feasible.

Between 2014 and 2016, at sub-national level, we additionally participated as observers in two national-level REDD + related meetings (Safeguards System Panel in Mexico City and the national consultation forum in Merida, Yucatán), and attended 22 REDD + related meetings and forum(s) (Mexico City, Guadalajara, Mérida, Campeche city, Noh Bec, Mixteca Alta, Región Sierra Norte, Región Istmo, Región Chinantla, Oaxaca de Juárez, Bolonchén, and Hopelchén) focused on a wide range of issues of the readiness initiatives (Fig. 1). During these meetings, we observed the actors' interactions and issues under discussion, capturing data directly related to our research topic and questions.

Interview transcripts and notes taken during meetings were analysed by identifying the issues raised and response patterns, subsequently creating subcategories and organizing it into coherent analytical categories. We then proceeded with the interpretation of data and compiling our results.

\section{Results}

\section{Representation and Concerns in Mexico's REDD + Readiness}

In Mexico, the Institutional Revolutionary Party (PRI) governed the country between 1929 and 2000 and designed public policy in a centralized and vertical fashion. The Party established the basis of the current authoritarian political culture (Cabrero-Mendoza 2000: 204). Public policies towards the rural sector were characterized by a clientelist aid-based approach, delivered in exchange for political loyalty. While the drug-economy and migration have offered alternatives to rural people, relative poverty has changed little over the period from 1990 to 2015, and economic inequality has widened (CONEVAL 2019). Critical and organized circles of peasants and Indigenous Peoples, however, have constantly mobilized, particularly over the last 25 years, to have their concerns and priorities taken seriously in Mexico's national polity and policy.

Due to longstanding struggles, Indigenous Peoples have historically advocated for participation rights, recently 
grounding their claims on international agreements and conventions, such as the 2007 UN Declaration on the Rights of Indigenous Peoples (UNDRIP, 2007) and the American Declaration on the Rights of Indigenous Peoples (ADRIP, 2016). The Mexican government signed most of these agreements and these norms are currently treated with the same importance as the national Constitution. The right to FPIC is a governmental duty and it is being as such incorporated into national and subnational legislations (e.g., in Chapter 2, Article 8 of Mexico's Law for Sustainable Forestry) (Carrillo and Velasco, 2016). This duty, however, is still far from guaranteed and rarely implemented in practice. Drawing on these human rights principles mandated by international law, the country's ENAREDD + emphasized that:

"The principles and safeguards of the ENAREDD+ must be inspired by the principles of inclusion and social and gender equality, indigenous peoples and communities' full and effective participation, respect to its rights, wisdom, organization forms as well of the fostering of its duties" (CONAFOR, 2017: 16; FCPF, 2014).

Participatory forums within Mexican environmental policy were established for the first time in the context of the 1996 reforms to the General Law for Ecological Equilibrium and Environmental Protection (LGEEPA) (Blauert et al., 2006). Although relatively abundant across many public policy domains, these forums have been questioned for their lack of transparency and accountability, and their opaque election mechanisms (Hevia et al., 2011). Two REDD + working groups were established by the National Forestry Council (CONAF), an advisory body established by The General Law for the Sustainable Development of Forestry (LGDFS), in addition to the national and state-based CTCs: the REDD + forum, on the one hand, and the Indigenous and Peasants' Organisations Roundtable on the other. We do not analyse these two here because they held fewer meetings than the CTCs and the discussions held therein did not greatly influence the ENAREDD +(Špirić et al., 2015). The government's Inter-Secretarial Commission for Climate Change (CICC) and the Inter-Secretarial Commission for Sustainable Rural Development (CIDRS) also provided inputs to the ENAREDD + and advice to on-the-ground pilot activities (Carrillo and Velasco, 2016; CONAFOR, 2014, 2017; Špiric, 2015).

Overall, this evidence suggests that the REDD + readiness process has been accompanied by either the establishment of dedicated forums for discussion and decision-making or the contribution of existing governmental bodies to the policy process. However, we question whether the most influential forum, i.e., the CTC, and the national consultation of the ENAREDD + have been procedurally just and whether this apparent breadth and depth of participation in REDD + readiness has lived up to procedural fairness principles.

The first meeting of the national CTC occurred in 2008 and several meetings were held annually until 2013 . These included representatives from federal state agencies, NGOs, social organizations from local communities, independent forestry associations, and forestry consultants, and took place in Mexico City, far from the rural communities where REDD + early activities would be implemented. To support the completion of the ENAREDD +, each meeting addressed aspects of what was to be included in the strategy and the minutes were distributed to a wider constituency for comments. An important member of the CTC who participated in all meetings over these years suggested to us that the committee was "a free, open and plural space for dialogue between society and government." However, he added:

"It was not representative, not balanced, nor equitable.

It was not established to be like that. The CTC does not design policy, it is instead a consultation body. There was no participation from the rural sector. At some point, there were a few subsidies to help with the attendance of campesinos, but it did not have their representation nor a balanced sectorial representation" (interview with CTC participant member, 09/22/2014).

This lack of participation of rural representatives, and forest landowners in particular, has been noted by others as a significant limitation of the committee (Carrillo and Velasco, 2016: 14). The Ministry of Rural Affairs (SAGARPA), considered a central actor for land-use policy in the ENAREDD + document, did not participate in most CTC meetings (ENAREDD + 2016). This was not a minor caveat, since important reductions in deforestation and forest degradation are unlikely to be achieved without the collaboration of this Ministry, nor without actors from the financial and land-use private sectors, who were also conspicuously missing in CTC meetings (Carrillo and Velasco, 2016; Špiric, 2015; Trench et al., 2018).

Despite starting with notable enthusiasm, actors' involvement in the CTC decreased during our study period (see also, Carrillo and Velasco, 2016; Špiric, 2015). Two national NGOs, i.e., Red MOCAF and RITA, left the meetings arguing that the CTC did not have legal status (interviews NGO 09/09/14; NGO 03/03/15, community member, 22/09/14). Other actors complained that the CTC's rule of one-vote per participant benefited those stakeholders who were able to send more attendees, such as national and international NGOs (Špiric, 2015: 137). Such unrealized expectations pushed these more critical Mexican NGOs towards the REDD + Working Group in CONAF, which could make decisions binding for CONAFOR given its legal status. Regardless of these representational disputes, the CTC strongly contributed to the design of the 
ENAREDD + (2016) and was a highly influential decisionmaking body in the readiness process.

Sub-national CTCs took a different shape in each state. Oaxaca stands out as a relatively successful example of social inclusion in the participatory process: it was the only one whose president was a member of civil society, and which advocated for a strong lead of forest owners in the REDD + process. Reflecting the level of importance granted to community forestry, this committee designated a voting seat for each region of Oaxaca's State Union of Community Foresters (UESCO) and all decisions had to be approved by this organization's members. Some actors in Oaxaca lamented, however, that the state government did not take the discussions very seriously, leaving NGOs rather alone in exploring ways in which REDD + could support the sustainability of the forestry sector (interview with government officer, 10/29/14). Conversely, a state-level forestry officer argued that decision-making in the state's CTC was captured by a small group of individuals who in turn excluded the state government officer acting as chairman. Subsequently, the state government invoked the state's climate change law, which grants decision-making power to the working group led by the state forestry office, and in so doing downgraded the state's CTC to a mere "consultation forum" (interviews with government officers 06/26/15; 02/07/15).

The CTC in Campeche had a more balanced but minimal representation of the agricultural, livestock, forestry, beekeeping, and hunting and fishing sectors. Communitybased organisations were, in contrast with Oaxaca, almost absent. The committee included representatives of the federal government, civil society, academics, and a few local authorities. Most of its members felt that they generally had both voice and vote. The president and vice-president's seats were reserved for an NGO member, while the secretary was the head of the state's environment ministry (Špiric, 2015). Some interviewed members, however, complained that the state's CTC did not progress at a good pace, it was onerous to travel long distances for the meetings, and that there was a notable decrease in members' attendance over time. Špiric et al. (2015: 148-129) explained this point as a problem of unsatisfied expectations, resulting in participant burnout.

The CTC in Oaxaca experienced more disputes and tensions than Campeche's. Oaxaca is divided into eight different regions, and NGOs normally limit their area of work to one region. The selection of REDD + early action areas was a controversial issue, as these selected areas could probably become the target of future REDD + funding (interview with government officer, 10/07/14, 27/10/14). "Everyone tries to get money to fall in their territories," argued an NGO representative (interview, 21/01/15). Others argued that the most deforested and abandoned regions should be selected as REDD + early action areas, while others replied that target REDD + investments should go to more advanced conservation programs where good practice could be established and in so doing inspire others with lower levels of institutional capacity (interviews with NGO member, 18/07/16; community advisor, 06/29/15; NGO member, 20/01/15; 28/10/14; 12/02/14).

More critically, some interviewees stated that Oaxaca's CTC only invited those who belonged to certain organizations or were close to specific individuals (interviews with community advisor, 04/14/16; NGO member, 12/12/14; $13 / 01 / 15)$. As a community member noted to us:

"The government's strategy is to persuade the leaders of the forestry [about REDD+ potential benefits]; they are the ones who are invited to meetings, aren't they? However, these leaders are not necessarily accountable to their communities. If REDD+ institutional actors do not provide to us, the community authorities, relevant and exhaustive information about REDD+, how can we inform our people about it? This is logical, how can I compromise my community? For any project authorization, we necessarily have to take it to the assembly. We cannot do anything without the assembly's approval" (interview with community leader, 15/01/15).

Feeling displaced within the CTC, some NGOs left and started participating in the meetings of another sub-nationallevel consultation forum known as Oaxaca's Climate Change Technical Advisory Committee, which was regarded as an opportunity to counterbalance the consultation deficit experienced (interview with NGO member, 12/12/14; 29/10/14).

\section{The National Consultation and Information-sharing at Local Level}

The consultations with local communities and Indigenous Peoples in Mexico have been plagued by irregularities and manipulation over the last few decades (Tauli-Corpus, 2018). The national REDD + consultation was aimed at presenting and discussing the final draft of the ENAREDD + throughout the country and fulfilling national and international law standards, such as Articles 1 and 2 of the Mexican Constitution, which mandate that any community directly or indirectly impacted by administrative or legislative actions must be consulted, Articles 1 to 7 of the ILO's 169 agreement, Article 1 of the UNDRIP, and Articles V and VI of the ADRIP, to cite the most important. The consultation spanned from January 2014 to August 2016 (CONAFOR, 2015, 2016), and put specific emphasis on the consultation of indigenous and afrodescended groups. The strategy was disseminated through 54 state-level consultation events, which encompassed 5,352 attendees from rural communities and indigenous 
and afro-descended groups. These in turn represented 212 communities from 161 municipalities across 23 states (SEMARNAT/CONAFOR, 2015; CONAFOR, 2016).

The consultation was divided into three phases: an informative phase that provided all relevant information related to the process; a consultative phase where participants expressed their views and concerns; and a dissemination phase where agreements and disagreement over the ENAREDD + were either reached or settled. The consultation report, however, only describes the outcomes of the dissemination activities and does not detail how information was provided nor if results were taken back to the communities for feedback and validation. It illustrates that communities delivered 3,882 proposals, all related to the seven components of the ENAREDD + (CONAFOR, 2016: 11). These proposals follow three main lines: (a) to respect indigenous rights, both those established by (inter) national law and those related to customary law; (b) to include women and youth in policymaking and improve communication with the government; and (c) to build capacity at local level for REDD + implementation and to guarantee sufficient resources for such purposes. Official sources report that consultative bodies, such as CONAF's REDD + Working Group and the indigenous and peasant organizations' roundtable, contributed enthusiastically to the design of the consultation strategy (SEMARNAT/ CONAFOR, 2015: 18).

During our fieldwork in Oaxaca and Campeche, actors expressed different opinions regarding the ENAREDD + consultation process. Some stated that the time for consultation and opportunities for participation and speaking were rigid and short: "One was left with the sensation of having been used," declared a participant (interview with academic, 09/11/16). During a workshop we organized in Mexico City in November 2016, another academic argued "...CONAFOR left the task [of implementing the national consultation] to CDI [the Indigenous Affairs Federal Office] which employs its own structures of representation. They have representatives for each indigenous group and operate in a very clientelist environment." The process was also described as "shoddy" by a national NGO member, while a member of CONAF's Working Group complained that land-use emissions' monitoring and reporting issues had "received five times more budget than the national consultation" in the ENAREDD + design phase. During the workshop, a representative of a peasant organization mused:

"Indigenous and forestry organisations do not yet see a social appropriation of REDD+ taking place. For example, it is still not clear who will own carbon rights, and what the technical proposal for benefit distribution is [...] socialization is needed, but it does not matter if we have 300 or 500 workshops when we do not have indicators. What is the real benefit for communities?" (Community member, 04/11/16).

In another REDD + consultation workshop held in the city of Merida in June 2018, a representative of a local organization stated that they had been asked by the state government to carry out a quick consultation process in a rural community without prior instructions, protocol, or supporting information to guide the process. The NGO was informed that the results of the consultation would be integrated into the national process that allegedly followed international law standards on Indigenous Peoples' consultation. Similar complaints have been reported by others. González Rojas (2016: 79-80), for example, points out that a member of an NGO in Oaxaca complained that the consultation of the ENAREDD + in the state did not follow the guidelines of the CDI protocol. He also highlights that this NGO member challenged the alleged inclusiveness of the process because some communities which were openly critical of the government's environmental policy were not invited to participate (ibid.).

Another flaw of the REDD + readiness phase extends beyond the limits of participation in the CTCs and the national strategy's consultation process: it concerns the poor understanding of REDD + by those involved in pilot activities. For example, most of the members from communities with pilot REDD + activities were unable to explain to us what REDD + was about when we visited them. Even when information was made available, implementation of consultation processes at the community level by the pilot project's management organization was rare. Several interviewees concurred with our observations (interviews with community member b, 15/01/15; academic, 13/01/15; government officer, 29/07/14; NGO members, 01/13/15; 10/28/14; $21 / 01 / 15 ; 20 / 01 / 15$ ).

The limits of REDD + information-sharing at local level were very apparent in the field. Several local actors pointed out that information flowed at higher policy levels, whilst people in rural communities could not access such information and, consequently, could not understand what REDD + readiness or pilot activities were about and or their long-term purpose. We were told that NGOs rarely visited the pilot projects and that they had not heard of the national consultation: "They just come, take the picture and leave," complained a community member (interview, 08/04/16). It was not surprising then that complaints in the field revolved around the lack of clear information on what the pilots were for, and what future REDD+ activities would look like.

Outside the communities, similar concerns were raised. An NGO staff member emphasized that "REDD has so far been business as usual, where NGOs speak on behalf of 
communities, ...with the process led by a conglomerate of international NGOs that are not attending pilot projects nor communities, and the government, which is not interested in communities' empowerment" (interview, 12/13/14), whilst an academic noted that "REDD has become a checklist where the government is only accountable to the upper social layer and has forgotten the base" (public comment, workshop in Mexico City, November 2016).

\section{Discussion}

Our analysis of participation dynamics in Mexico's REDD + readiness phase reveals serious inadequacies throughout the process, particularly regarding the inclusion of peasant and indigenous communities in discussions to prepare the strategy, first, and to disseminate it throughout the country later. These inadequacies in our view, centre on a critical lack of information about REDD + , particularly at the local level, limited recognition of who ought to be subjects of REDD + discussions and implementation, and insufficient representation of and engagement with communities' institutions and values during the design of the national strategy.

First, lack of awareness about the global REDD + initiative (e.g., its governing principles, how it has been funded, and how it might work in the future), underlying policy discussions, its operationalizing principles, and the practice of individual pilot projects is plainly evident. REDD + implementers frequently omitted providing basic information to rural communities, failing to comply with the principle of free, prior, and informed consent established in international law frameworks such as ILO's 169 convention and UNDRIP. Second, we show that the active role of committees and working groups set up by the federal and state governments was insufficient to allow some actors, particularly grassroot organizations and communities, or encourage others, like those involved directly or indirectly in deforestation, to become informed and involved more thoroughly in the policy process. Although peasants' organizations did have a seat on consultation committees, their recognition and representation in these forums was limited, as was also the case for private sector representatives, who most likely self-excluded from the process. This representation gap, particularly of local communities, characterizes a continuation of the longstanding violation of the principle of inclusion of indigenous peoples and peasants in the design of REDD + policy, which has also been documented in other countries (Satyal et al., 2019; Satyal, 2018; Pham et al., 2014; Hoang et al., 2019; Suiseeya, 2017; Mbeche, 2018). The representation gap we observed also calls for the recognition of socially differentiated community groups of various kinds in public policy, and for tackling the structural conditions that discriminate against these groups. Environmental policymaking should not reproduce the historical marginalization of peasants, indigenous people, women, and youth (see also Martin et al., 2016; Satyal et al., 2019; Young, 2000).

Third, we also demonstrate that REDD + policymaking and pilot projects' implementation has not sufficiently acknowledged the importance of community initiatives, knowledge, and values. As our findings illustrate, there is a contradiction between state-sponsored and institutionalized practices of participation versus the communities' democratic experiences and practices that have triggered sustainable resource management experiences (Rendón \& Ballesteros, 2003; Toledo \& Ortiz, 2014). The former has fallen short of promoting meaningful participation and limiting it to bounded spaces of the institutional sphere, while the latter has been critical to achieve local, sustainable initiatives. Although praised for being more inclusive than state controlled environmental policy processes (which are sometimes constrained by bureaucratic complexity or limited to a tick-box exercise; see also (Lund, 2015) for similar observation elsewhere), ongoing participatory spaces under Mexico's multilevel REDD + governance are still centralized, disconnected across scales, costly, unequal, and ineffective. Such cross-scalar disconnect has not only hindered effective operationalization and socialization of REDD + related policies (e.g., implementation of free, prior, and informed consent) but also limited participation of some important local and sub-national actors in national policymaking (making it a costly and time-consuming experience). Rural organizations' representatives, for instance, struggle to travel to the capital cities, and therefore have a minimal presence vis-à-vis civil society organizations and government representatives in the public forums. Furthermore, as we observed, the consultation process, far from the community's reach, is not open to scrutiny and the official reports are uncritical or without clear assessment indicators. These shortcomings might be an outcome of institutional inertias and political agendas of national and global institutional actors. For instance, the budget allocated to field staff, field projects, community planning processes, and learning communities was low, in contrast to the strong priority given to inter-institutional collaborations and onerous consulting. By choosing to unequally allocate funds to technical aspects of REDD + development and implementation (e.g., carbon assessment and wider Monitoring, Reporting, and Verification), REDD + institutional actors ignore important issues such as human rights' principles of self-determination, procedural justice, equality, and accountability (see also Satyal et al., 2019 for similar findings in Nepal's REDD + process).

Community institutions and political participation have been central to the success of community forestry enterprises in our study region, i.e., the states of Oaxaca and those of the Yucatan Peninsula (Bray et al., 2006). Sustainable forest 
management and community-based enterprises were the result of historic, cultural, socio-political, and institutional processes. Local organization is key to trigger community forest management schemes and learning from it and accommodating these processes should be considered more prominently by policymakers and REDD + actors. Therefore, we suggest that future REDD + implementation, particularly in these contexts, should be reconceptualised by focusing practices on the collective knowledge and aspirations of those who have achieved sustainable management, in other words, under the rationale of wider participation of forest communities (rather than only those officially recognized as institutional actors). This enterprise requires undertaking long-term processes of respectful and more accountable collaboration with indigenous peoples and local communities, as well as an ethical commitment of consulting the legitimate community forums, as some authors have suggested (Martin et al., 2016; Rendón-Monzón \& Ballesteros-Rojo, 2003). Some organizations implementing pilot projects have taken important steps in this regard, but a different and more efficient paradigm of participation and collaboration between communities and institutions/organisations will emerge if there is institutional will to adapt to community forms of organization, natural resource management, and environmental knowledge. Several examples show that these principles are being put into practice in many community spaces of rural Mexico (Fuente, 2012; Fuente \& Barkin, 2012; Toledo $\&$ Ortiz, 2014), with actions that can also harmonize with the notions of procedural justice (Schlosberg, 2004; Sikor, 2014; Sikor \& Stahl, 2011).

\section{Conclusion}

We examined the participatory instruments and processes that have provided key design inputs to Mexico's national REDD + strategy. Drawing on interviews and field observations, we highlighted the main contradictions between the mainstream understanding and experience of participation in Mexico's REDD + readiness by most of the involved actors and the theoretical standards set by the procedural justice and participation literatures. Despite widespread agreement among participating actors about the unusual openness of REDD + policy design spaces, we found, first, a lack of involvement of public and private actors responsible for deforestation in the ENAREDD+drafting process. Second, we shed light onto the limited involvement of community representatives and members in REDD + policy spaces, and the deficient information-sharing systems put in place to reach out to these actors, which reflect in turn the rather top-down character of the REDD + readiness phase. Finally, we show the rather limited engagement with local institutions and worldviews throughout the REDD + readiness process, including the ENAREDD+drafting process and the pilot projects.

To conclude, we believe that putting communities and their institutions at the centre of REDD + decision-making is critical for more effective and legitimate buy-in of this global environmental policy. Placing communities at the centre of ongoing and future REDD + decisions has the potential to transform relations and communication between institutional actors and communities towards a more just collaboration and, therefore, more legitimate and likely effective implementation (Pascual et al., 2014). However, the research presented here suggests that there are inertias deeply rooted in institutional practices and values which may impede such necessary transformation. Communities, and their institutions, remain a blind spot in the narratives and practices of state institutions and even of most civil society organizations, at least in the context of REDD+. This ignores the fact that local communities are rights bearers who must be properly informed and consulted as peers with all other forest stakeholders and be considered key decisionmakers. With particular attention to participation and procedural justice issues, the chances of REDD + effectiveness and legitimacy will greatly increase in the long term. Key insights and lessons on REDD + participation dynamics can also be useful in other emerging domains of environmental policymaking, such as in the operationalization of the Post-2020 Global Biodiversity Framework (currently under development and negotiation) into national contexts, particularly in terms of strengthening the role, rights, and participation of indigenous peoples and local communities in the updating and implementation of biodiversity policies.

Funding This research was funded by the 'Conflict and Cooperation over REDD+ in Mexico, Nepal and Vietnam' project, supported by the Netherlands Organisation for Scientific Research and the UK Department for International Development (Grant No W07.68.415). EC acknowledges the financial support of the UAB-Banco de Santander Talent Retention Programme and notes that this work contributes to ICTA-UAB "Unit of Excellence” (MinECo, MDM2015-0552).

\section{Declarations}

Informed Consent Informed consent was obtained for all respondents and research was conducted in line with the ethical standards established and approved by the authors' institutions and following usual social sciences approaches.

Conflict of Interest The authors declare that they have no conflict of interest.

Open Access This article is licensed under a Creative Commons Attribution 4.0 International License, which permits use, sharing, adaptation, distribution and reproduction in any medium or format, as long as you give appropriate credit to the original author(s) and the source, provide a link to the Creative Commons licence, and indicate if changes were made. The images or other third party material in this article are 
included in the article's Creative Commons licence, unless indicated otherwise in a credit line to the material. If material is not included in the article's Creative Commons licence and your intended use is not permitted by statutory regulation or exceeds the permitted use, you will need to obtain permission directly from the copyright holder. To view a copy of this licence, visit http://creativecommons.org/licenses/by/4.0/.

\section{References}

ADRIP - American Declaration on the Rights of Indigenous Peoples. (2016). http://cdn7.iitc.org/wp-content/uploads/AG07150E06_ web.pdf. [Retrieved, April 14, 2020]

Bayne, J., Herbohn, J., Smith, C., Fischer, R., \& Bray, D. B. (2015). Key factors which influence the success of community forestry in developing countries. Global Environmental Change, 35, $226-238$.

Blauert, J., Rosas, M., Anta, S., \& Graff, A. (2006). ¿Espacios para la deliberación o toma de decisiones? Lecciones para la participación y las políticas en consejos ambientales en México. In V. Isunza, E. Olvera, \& A. Olvera (Eds.), Democratización, rendición de cuentas y sociedad civil: Participación ciudadana y control social (pp. 597-639). CIESAS/Universidad Veracruzana/ Miguel Porrua.

Boutthavong, S., Hyakumura, K., \& Ehara, M. (2017). Stakeholder Participation in REDD+ Readiness Activities for Three Collaborative Projects in Lao PDR. Forests, 8, 150.

Bray, D., Antinori, C., \& Torres-Rojo, J. M. (2006). The Mexican model of community forest management: The role of agrarian policy, forest policy and entrepreneurial organization. Forest Policy and Economics, 8, 470-484.

Broberg, M., \& Sano, H.-O. (2018). Strengths and weaknesses in a human rights-based approach to international development - an analysis of a rights-based approach to development assistance based on practical experiences. The International Journal of Human Rights, 22(5), 664-680.

Cabrero-Mendoza, E. (2000) 'Mexican local governance in transition: fleeting change or permanent transformation?', The American Review of Public Administration, 30(4): 374-388. https:// doi.org/10.1177/02750740022064722

Carrillo-Fuentes, J., \& Velasco-Ramírez, A. (2016). Estudio legal. Facultades y responsabilidades del manejo forestal y del suelo ante REDD+ en México. Ocassional document 150. CIFOR.

Cernea, M. M. (1985). Putting people first. Sociological variables in rural development. Oxford University Press.

Chambers, R. (2000). Whose reality counts? ITDG Publishing.

Chapela, F. (1999). Emergencia de las organizaciones sociales de Oaxaca: La lucha por los recursos forestales. Alteridades, 9(17), $105-102$.

CONAFOR - Comisión Nacional Forestal. (2017). Estrategia Nacional REDD+ (ENAREDD+), http://www.enaredd.gob. $\mathrm{mx} /$. [Retrieved, January 15, 2017]

CONAFOR. (2014). Sesiones Ordinarias CONAF 2014.. Retrieved June 8, 2017, from http://www.gob.mx/conafor/documentos/ sesiones-ordinarias-conaf-2014

CONAFOR. (2015). Plan de Consulta de la Estrategia Nacional de Reducción de Emisiones por Deforestación y Degradación Forestal (ENAREDD+). http://www.enaredd.gob.mx/wp-content/ uploads/2014/11/Plan-de-consulta-ENAREDD_Mayo2014.pdf. [Retrieved, June 8, 2017]

CONAFOR. (2016). Informe final de la consulta a comunidades indígenas y afrodescendientes para la construcción de la Estrategia Nacional REDD+. http://www.enaredd.gob.mx/wp-content/uploads/2017/03/ Informe-Final-Consulta-Indigena.pdf. [Retrieved, June 2, 2017]
CONAFOR. (n.d. A). Forest Carbon Partnership Facility (FCPF). Readiness Preparation Proposal (RPP). http://forestcarbonpartnership. org/sites/fcp/files/Documents/tagged/Mexico_120211_R_PP_ Template_with_disclaimer.pdf. [Retrieved, January 16, 2017]

CONEVAL - Comisión Nacional de Evaluación de la Política de Desarrollo Social. 2019. Estimaciones del CONEVAL con base en la ENIGH y el MCS-ENIGH. https://www.coneval.org.mx/ Medicion/EDP/Paginas/Datos-censales.aspx. [Retrieved April 17, 2019]

Cooke, B., \& Kothari, U. (Eds.). (2001). Participation: The new tyranny? Zed Books.

Daviet, F. (2011). A draft framework for sharing approaches for better multi-stakeholder participation practices. Forest Carbon Partnership Facility and UN-REDD Programme.

Ellis, E. A., Kainer, K. A., Sierra-Huelsz, J. A., Negreros-Castillo, P., Rodriguez-Ward, D., \& DiGiano, M. (2015). Endurance and Adaptation of Community Forest Management in Quintana Roo, Mexico. Forests, 6, 4295-4327.

Epstein, S. E., \& Wickham-Crowley, T. P. (Eds.). (2011). Struggles for social rights in Latin America. Routledge.

FCPF - Forest Carbon Partnership Facility. (2014). Directrices sobre la participación de las partes interesadas en la preparación para REDD+ con énfasis en la participación de los pueblos indígenas y otras comunidades cuyo sustento. https://www.google.com/ url $? \mathrm{sa}=\mathrm{t} \& \mathrm{rct}=\mathrm{j} \& \mathrm{q}=\& \mathrm{esrc}=\mathrm{s} \&$ source $=$ web $\& \mathrm{~cd}=1 \& \mathrm{ved}=$ 2ahUKEwiQ68GNk-3oAhUFJhoKHaeDADkQFjAAegQIAxAC \&url=https $\% 3 \mathrm{~A} \% 2 \mathrm{~F} \% 2 \mathrm{Fwww}$.unredd.net $\% 2 \mathrm{Fdocuments} \%$ 2Fglobal-programme-191\% 2Fstakeholder-engagement295\%2Fkey-documents-1095\%2F8210-directrices-des-fcpf-yel-programa-onu-redd-para-el-involucramiento-de-las-partesrelevantes-en-la-preparacion-para-redd-8210\%2Ffile.html\& usg=AOvVaw3u0SxIn4yorHunc_j0i9i_. [Retrieved June 5, 2017]

Fuente-Carrasco, M., \& Barkin, D. (2012). Los procesos de apropiación social de la naturaleza en comunidades rurales: Retos epistémicos para el análisis económico de las instituciones. In M. F. Fuente-Carrasco, Conocimiento indígena contemporáneo y patrimonio biocultural en la Sierra Juárez de Oaxaca. Aportaciones empíricas y (pp. 99-132). Ixtlán de Juárez: Instituto de Estudios Ambientales.

Fujisaki, T., Hyakumura, K., Scheyvens, H., \& Cadman, T. (2016). Does REDD+ Ensure Sectoral Coordination and Stakeholder Participation? A Comparative Analysis of REDD+ National Governance Structures in Countries of Asia-Pacific Region. Forests, 7, 195.

González-Rojas, A. (2016). Las consultas de la CONAFOR a comunidades indígenas para la Estrategia Nacional de Reducción de Emisiones por Deforestación y Degradación de los Bosques (ENAREDD+). La nueva servidumbre agraria y la resistencia indígena y campesina. Bajo el Volcán, 15(23), 113-129.

Hevia, F., Vergara-Lope, S., Avila Landa, H. (2011). Participación ciudadana en México: consejos consultivos e instancias públicas de deliberación en el gobierno federal, Perfiles Latinoamericanos, 38, 65-88).

Hickey, S. \& Mohan, G. (2005). Participation: From tyranny to transformation. Exploring new approaches to participation in development. The Chicago: Zed Books.

Hoang, C., Satyal, P., \& Corbera, E. (2019). "This is my garden": Justice claims and struggles over forests in Vietnam's REDD+. Climate Policy, 19(sup1), S23-S35.

ILO - International Labour Organization. (1989). C-169 Indigenous and Tribal Peoples Convention. Technical Convention. Geneva: International Labour Organisation. https://www.ilo.org/dyn/ normlex/en/f?p=NORMLEXPUB:12100:0::NO::P12100_ILO_ CODE:C169. [Retrieved April, 14, 2020] 
Lawlor, K., Madeira, E. M., Blockhus, J., \& Ganz, D. J. (2013). Community Participation and Benefits in REDD+: A Review of Initial Outcomes and Lessons. Forests, 4, 296-318.

Lund, J., \& F. . (2015). Paradoxes of participation: The logic of professionalization in participatory forestry. Forest Policy and Economics, 60, 1-6.

Martin, A., Coolsaet, B., Corbera, E., Dawson, N., Fraser, J. A., Lehman, I., \& Rodríguez, I. (2016). Justice and conservation: The need to incorporate recognition. Biological Conservation, 197, 254-261.

Mbeche, R. (2018). Climbing the ladder of participation: Symbolic or substantive representation in preparing Uganda for REDD+? Conservation and Society, 15(4), 426-438.

McCall, M. (2016). Beyond "landscape" in REDD+: The imperative for "territory". World Development, 85, 58-72. Mustalahti, I., Cramm, M., Ramcilovic-Suominen, S.,

Mustalahti, I., Cramm, M., Ramcilovic-Sunominen, S., and Tegegne, Y.T. (2017) 'Resources and rules of the game: participation of civil society in REDD+ and FLEGT-VPA processes in Lao PDR', Forests, 8 (2), 50. https://doi.org/10.3390/f8020050

Pascual, U., Phelps, J., Garmendia, E., Brown, K., Corbera, E., Martin, A., Muradian, R., \& Gómez-Baggethun, E. (2014). Social equity matters in Payments for Ecosystem Services. BioScience, 64(11), $1027-1036$.

Pham, T. T., Di Gregorio, M., Carmenta, R., Brockhaus, M., \& Le, D. N. (2014). The REDD+ policy arena in Vietnam: Participation of policy actors. Ecology and Society, 19(2), 22.

Rendón-Monzón, J., \& Ballesteros-Rojo, M. (2003). La comunalidad: Modo de vida de los pueblos indios. Consejo Nacional para la Cultura y las Artes.

Satyal, P. (2018). Civil society participation in REDD+ and FLEGT processes: Case study analysis from Cameroon, Ghana, Liberia and the Republic of Congo. Forest Policy and Economics, 97, 83-96.

Satyal, P., Corbera, E., Dawson, N., Dhungana, H., \& Maskey, M. (2019). Representation and participation in formulating Nepal's REDD+ approach. Climate Policy, 19(sup1), S8-S22.

Schlosberg, D. (2004). Reconceiving environmental justice: Global movements and political theory. Environmental Politics, 13(3), $517-540$.
SEMARNAT/CONAFOR. (2015). Consulta a comunidades indígenas y afrodescendientes para la construcción de la estrategia nacional $R E D D+$. Mexico: SEMARNAT/CONAFOR.

Sikor, T. (2014). The Justices and Injustices of Ecosystem Services. Earthscan.

Sikor, T., \& Stahl, J. (2011). Introduction: The rights-based agenda in International Forestry. In T. a. Sikor, Forest and People. Property, governance and human rights, pp. 1-13. London: Earthscan.

Špiric, I. (2015). Uncovering REDD+ readiness in Mexico. Actors, discourses and benefit sharing. PhD Thesis. PhD Programme for Environmental Science and Technology, Universitat Autónoma de Barcelona.

Suiseeya, K. R. M. (2017). Contesting justice in global forest governance: The promises and pitfalls of REDD+. Conservation and Society, 15(2), 189-200.

Tauli-Corpus, V. (2018). Report of the Special Rapporteur on the rights of indigenous peoples on her visit to Mexico. A/HRC/39/17/ Add.2. https://documents-dds-ny.un.org/doc/UNDOC/GEN/G18/ 192/94/PDF/G1819294.pdf?OpenElement. [Retrieved April 16, 2019]

Toledo, V., \& Ortiz-Espejel, B. (2014). México. regiones que caminan a la sustentabilidad. Una geopolítica de las resistencias bioculturales. Mexico: Universidad Iberoamericana Puebla.

Trench T., Larson A.M., Libert Amico, A., Ravikumar, A. (2018). Analyzing multilevel governance in Mexico: Lessons for REDD+ from a study of land-use change and benefit sharing in Chiapas and Yucatán. Working Paper 236. Bogor, Indonesia: CIFOR.

UNDRIP - United Nations Declaration on the Rights of Indigenous Peoples, (2007). https://www.un.org/development/desa/indigenouspeopl es/declaration-on-the-rights-of-indigenous-peoples.html. [Retrieved, April 14, 2020]

UNFCCC (2011) Report of the Conference of the Parties on its sixteenth session, held in Cancun from 29 November to 10 December 2010. Available at: https://unfccc.int/resource/docs/2010/cop16/ eng/07a01.pdf. (Accessed 10 November 2020)

Young, I. (2000). Inclusion and Democracy. Oxford University Press.

Publisher's Note Springer Nature remains neutral with regard to jurisdictional claims in published maps and institutional affiliations. 